\title{
Characteristics of Liquid Smoke of Red Fruit (Pandanus conoideus. L.) Waste with Pyrolysi: Method and Potentially as Biopesticide
}

\author{
Fransisca Christina Dewi ${ }^{1} \square$ Sumiyati Tuhuteru ${ }^{2}$, Andi Aladin ${ }^{3}$ and dan Setiyawati Yani ${ }^{4}$ \\ ${ }^{12}$ Agricultural lecturer, Petra Baliem Wamena College of Agricultural Sciences, Sanger Street Potikelek, Wamena, Papua 99511, \\ Indonesia \\ ${ }^{34}$ Chemical Engineering lecturer, Faculty of Industrial Technology, Universitas Muslim Indonesia, UMI, Makassar, Sulawesi \\ Selatan 90231, Indonesia
}

$\square$ Corresponding Author: Fransisca Christina Dewi, E-mail: franciesca.christ11@gmail.com

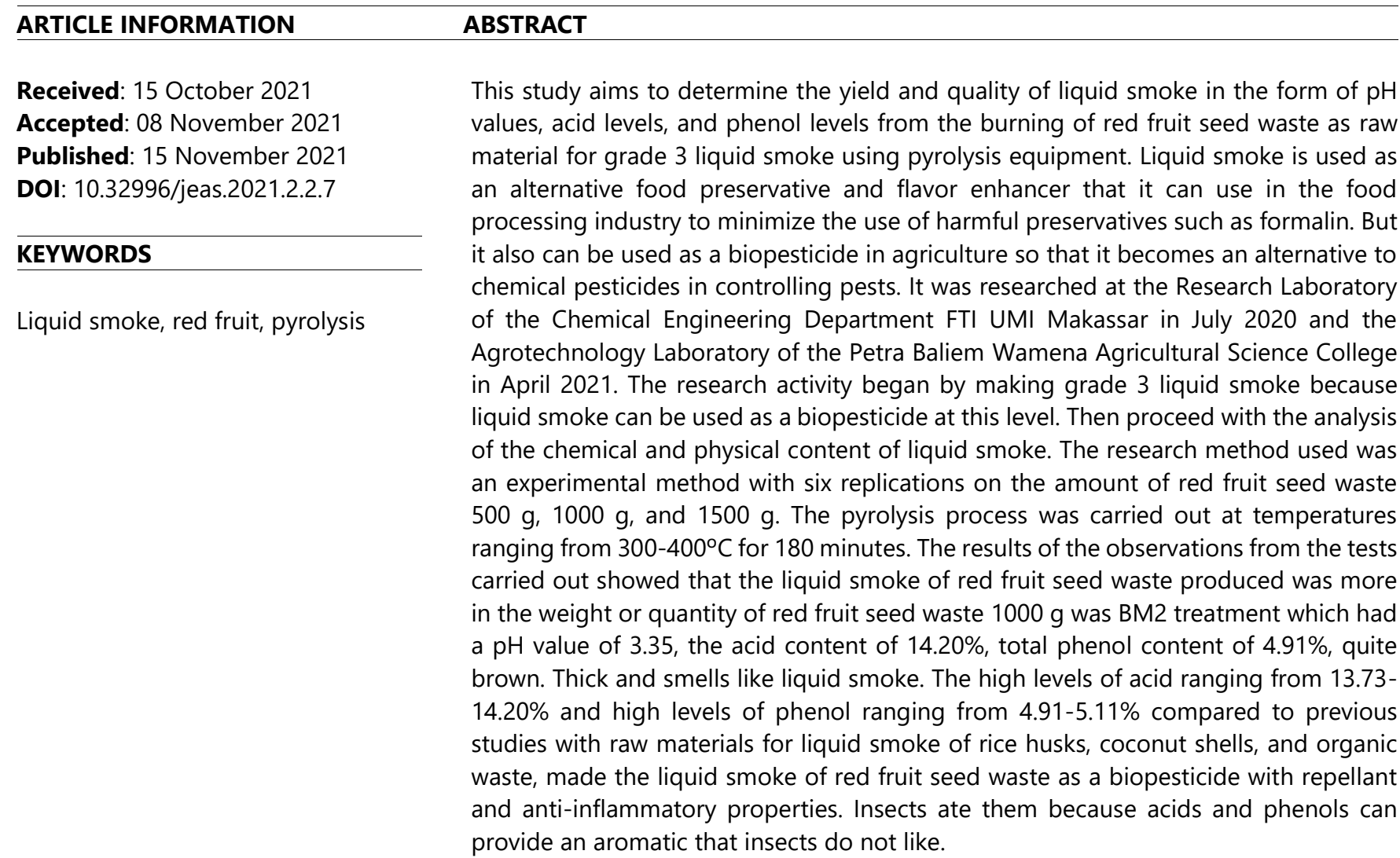

\section{Introduction}

Papua is the centre of red fruit production, making red fruit one of the typical plants or endemic plants of Papua because it is known that it can only grow well in Papua. The utilization of red fruit itself leaves waste which is mostly not utilized. The waste is in the form of fibrous seeds resembling coconut fibers. Based on the shape and characteristics that contain cellulose, hemicellulose, and lignin, red fruit seed waste has the potential as raw material for making liquid smoke. The chemical composition of the liquid smoke raw materials greatly determines the chemical quality and functional properties of the liquid smoke produced. It is important to know the basics of selecting raw materials that it will use to produce liquid smoke that has good potential to be used as a biopesticide in terms of its function. It is well known that pyrolysis is a process of lignocellulosic breakdown through combustion under limited oxygen conditions which produces gaseous substances in the form of smoke, liquids in the form of tar, and solids in

Copyright: (C) 2021 the Author(s). This article is an open access article distributed under the terms and conditions of the Creative Commons Attribution (CC-BY) 4.0 license (https://creativecommons.org/licenses/by/4.0/). Published by Al-Kindi Centre for Research and Development, London, United Kingdom. 
the form of charcoal, the amount of which depends on the type of material, method and conditions of pyrolysis (Lingbeck, et al., 2014). It also explained that the three main elements of wood are cellulose, hemicellulose, and lignin (Girard, 1992; Yusnaini \& Indah, 2014; Cadwallder, 2007). Therefore, all types of agricultural biomass consisting of cellulose, hemicellulose, and lignin can potentially be used as raw materials for liquid smoke. It is generally known that liquid smoke can be used as a substitute for food preservatives or extend the shelf life of products (Yusnani \& Indah, 2014; Herwati, et al.,2017; Ariestya, et al., 2016; Sarwendah, et al., 2016; Assidiq, et al., 2019). As a preservative to food, liquid smoke based on its properties, liquid smoke can provide many benefits for human life. Liquid smoke has been widely used in everyday life including as an inhibitor of bacterial growth (Dien, et al., 2019), insecticides (Wagiman, et al., 2014), pesticides (Sari, et al., 2018; Suhanda, 2016) latex coagulation (Sarbini, et al., 2018; Vachlepi, R \& R. Ardika, 2019), corrosion prevention on lead metal (Vachlepi A \& D. Suwardin, 2015), lead metal binder (A'yuni, et al., 2017). This study aims to obtain the yield value and quality characteristics of liquid smoke from the pyrolysis integration tool in the amount of red fruit seed waste different from a predetermined temperature. Yunus (2011), reported that the best quality of liquid smoke from coconut shells obtained from a pyrolysis temperature of $400^{\circ} \mathrm{C}$ and a pyrolysis time of 180 minutes showed that the liquid smoke produced contained $4.13 \%$ phenolic compounds, $11.3 \%$ carbonyl, and $10.2 \%$ acid.

Meanwhile, Zultinar (2014), also reported that the best quality of liquid smoke from durian skin was obtained from a pyrolysis temperature of $350^{\circ} \mathrm{C}$ and a pyrolysis time of 150 minutes with a yield of $26.52 \%, \mathrm{pH} \mathrm{3.3}$, acid content $0.211 \mathrm{~N}$, and density 0.973 $\mathrm{gr} / \mathrm{ml}$. Based on this, in this study, the temperature limit of the pyrolysis tool ranged from $300-400^{\circ} \mathrm{C}$, which was carried out for 180 minutes to produce the best yield of liquid smoke of red fruit seed waste. However, it is necessary to know the quantity of the best raw material for red fruit seed waste to conduct a quantity test of the liquid smoke of red fruit seed waste.

\section{Research Methods}

\subsection{Materials and Equipment}

The materials used in the manufacture of liquid smoke are using red fruit seed waste as raw materials and water to help condensate smoke. The tools used in the process of making liquid smoke are pyrolysis reactors, condensers, and thermocouples. The equipment used to test and analyze liquid smoke is a measuring cup, thermometer, $\mathrm{pH}$ meter, Erlenmeyer flask, oven, test tube, dropper, UV-Vis Spectrophotometer, and GCMS (Gas Chromatography-Mass Spectrometer).

\subsection{Research Methods}

The Determination of the weight or quantity of the raw material for the liquid smoke of the red fruit seed waste has been adjusted to the capacity of the existing pyrolysis reactor. Because its size is relatively small and quite simple, it is necessary to determine the appropriate weight or quantity of raw materials. The method used in this research is an experimental method with different weight or quantity treatment of pyrolysis raw materials, namely $500 \mathrm{~g}, 1000 \mathrm{~g}$, and $1500 \mathrm{~g}$ with pyrolysis and condensation methods. The temperature used ranged from $300-400^{\circ} \mathrm{C}$ and was carried out for 120 minutes. Furthermore, research preparation, research implementation, liquid smoke purification, and parameter observation are carried out.

\subsection{Research Procedure}

The procedure for the activities carried out in this research includes the preparation of tools and materials used during the research, implementation, and testing related to the characteristics of the liquid smoke produced. Preparation of tools and materials to be used begins with preparing raw materials for red fruit seed waste, which must dry first. The water content of red fruit seeds is calculated using the oven method to ensure the water content has run out. Furthermore, the red fruit seed waste is ready to be put into the pyrolysis reactor room, then condensed. The liquid smoke obtained from the pyrolysis results is accommodated in a container. Then the resulting liquid smoke is deposited for \pm one week and filtered. Then the most important thing is to test the physical and chemical characteristics of the liquid smoke produced.

\subsection{Research Parameters}

\subsubsection{Liquid Smoke Yield}

The liquid Smoke yield is the ratio of the amount (quantity) of the product produced from material extraction. Yield is expressed in percent (\%). The higher the yield, the higher the quality of the process that occurs. Yield can be calculated using Equation 1.

Yield $(\%)=\frac{\text { Volume of liquid smoke }(\mathrm{gr})}{\text { Weight of raw material }(\mathrm{gr})} \times 100 \%$

\subsubsection{Liquid Smoke Quality}

Liquid Smoke quality includes $\mathrm{pH}$ value, acid content, and total phenol by following the Japanese quality standards (Yatagai, 2002) are presented in table 1.

Table 1. Japanese specification liquid smoke quality standard 


\begin{tabular}{ll}
\hline Parameters (parameters) & Quality of liquid smoke (Quality of liquid smoke) \\
\hline $\mathrm{pH}$ & $1.5-3.7$ \\
Acid Content \% & $1-18$ \\
Phenol (Phenol) \% & - \\
Color (Color) & Yellow - Reddish Brown \\
Aroma & - \\
\hline
\end{tabular}

Source: Yatagai (2002)

\subsection{3 $\mathrm{pH}$ Value}

To determine the $\mathrm{pH}$ value of the liquid smoke produced, this study determined the $\mathrm{pH}$ using a digital $\mathrm{pH}$ meter by first dipping the electrode into distilled water, then drying it with a tissue. Then the electrode was inserted into the liquid smoke sample. Then calibration was carried out using $\mathrm{pH} 4$ and 7 buffers. Note the value of the degree of acidity $(\mathrm{pH})$ that appears on the monitor screen.

\subsubsection{Acid Level}

To determine the acid content of liquid smoke, as much as $2 \mathrm{ml}$ of liquid smoke is mixed with $20 \mathrm{ml}$ of aquadest and mixed until homogeneous. Then the solution weighed as much as 2 grams and added three drops of phenolphthalein indicator. The answer was titrated with $0.1 \mathrm{~N} \mathrm{NaOH}$ until a purplish red color. Furthermore, the acid content of liquid smoke is calculated using the calculation of equation 2 .

Acid content $==\frac{V \text { titer } \times N \text { NaOH } \times f p \times 60}{B S \times 1000} \times 100 \% \ldots \ldots .(2)$

It is known that $\mathrm{V}$ titer is the volume of $\mathrm{NaOH}$ used in $\mathrm{ml}, \mathrm{N} \mathrm{NaOH}$ is normality. $\mathrm{NaOH}$, $\mathrm{BS}$ is the sample weight in gr, and $\mathrm{fp}$ is the diluent factor.

\subsubsection{Total Phenol Level}

Content in liquid smoke was measured using a spectrophotometer. A sample of $0.5 \mathrm{mg}$ of liquid smoke was prepared diluted with $10 \mathrm{ml}$ of ethanol to determine the phenol content in the resulting liquid smoke. The mixture was taken $0.1 \mathrm{ml}$ and diluted with distilled water to $8 \mathrm{ml}$. it put the solution into a test tube, and then it added the mixture $0.5 \mathrm{ml}$ of $10 \%$ Folin-Ciocalteu reagent. Mix in a vortex for 1 minute. It added $1.5 \mathrm{ml}$ of sodium carbonate $\left(\mathrm{Na}_{2} \mathrm{CO}_{3}\right) 20 \%$ and left at room temperature for 60 minutes. Then the absorbance was measured at $755 \mathrm{~nm}$ using a UV-Vis Spectrophotometer. Furthermore, the total phenol content was calculated using Equation 3.

Total Phenol content $=\frac{x \cdot V \cdot f p}{B S} \times 100$

It is known that $\mathrm{x}$ is the concentration in $\mathrm{g} / \mathrm{ml}, \mathrm{V}$ is the sample volume in $\mathrm{ml}$, $\mathrm{fp}$ is the diluent factor, and $\mathrm{BS}$ is the weighted sample in grams.

\section{Results and Discussion}

\subsection{Quality of Raw Materials Liquid Smoke Waste of Red Fruit Seeds}

As it is known that pyrolysis is a process of lignocellulosic breakdown through combustion under limited oxygen conditions which produces gaseous substances in the form of smoke, liquids in the form of tar, and solids in the form of charcoal whose amount depends on types of materials, methods, and conditions of pyrolysis (Lingbeck, et al., 2014). It also explained that the three main elements of wood are cellulose, hemicellulose, and lignin (Girard, 1992; Yusnaini \& Indah, 2014; Cadwallder, 2007). Therefore, to ensure that the red fruit seed waste is suitable for use as raw material for making liquid smoke, cellulose, hemicellulose, and lignin content test is carried out. Based on the test results presented in table 2, it can see that the raw material of red fruit seed waste can be used as raw material for liquid smoke because it contains cellulose, hemicellulose, and lignin which support in producing good liquid smoke.

Table 2. Test parameters for cellulose, hemicellulose, lignin as raw materials for liquid smoke from red fruit seed waste 


\begin{tabular}{lll}
\hline Parameters for & analysis Results & Of Unit \\
\hline Cellulose & $37.68-38.95$ & $\%$ \\
Hemicellulose & $13.76-15.95$ & $\%$ \\
Lignin & $32.79-34.41$ & $\%$ \\
\hline
\end{tabular}

Source: PSPG UGM lab test (2020)

\subsection{Liquid Smoke Yield}

Yield is the result of dividing the amount of liquid smoke produced by the number of raw materials used and expressed in percent. In determining tool performance, the resulting yield needs to be taken into account. The yield produced in the pyrolysis process of red fruit seed waste for 180 minutes ranged from 17.8 to $50.6 \%$. The yields of the three treatments had significantly different values, but not for the liquid smoke produced because they had not too different values. The difference in the amount of liquid smoke yield in the treatment of the weight or quantity of raw material for red fruit seed waste is caused by the capacity or capacity of the pyrolysis reactor tube used. It is also influenced by changes in temperature during combustion, which directly affect the amount of condensed smoke. As stated by Haji et al., [20] that pyrolysis at temperatures that are too high will cause the formation of liquid smoke to decrease because the smoke produced is not entirely condensed. The yield of liquid smoke produced is still low due to the distribution of heat in the furnace being still not too evenly distributed and seen from the condition of the raw materials for the rest of the combustion that has not been wholly charred into charcoal.

Table 3. The average value of the liquid smoke yield of red fruit seed waste.

\begin{tabular}{|l|l|l|}
\hline Treatment & Liquid Smoke $(\mathrm{ml})$ & Yield $(\%$ \\
\hline BM1 & 253 & 50.6 \\
\hline BM2 & 372 & 37.2 \\
\hline BM3 & 267 & 17.8 \\
\hline
\end{tabular}

Based on Table 3, the yield produced in each treatment showed different results. The yield produced decreased in line with the increase in raw materials through the liquid smoke pyrolysis process. Grade 3 is liquid smoke that has been filtered. Seeing these results, recommendations for the weight or quantity of red fruit waste raw materials are suitable for the reactor tube capacity. The pyrolysis used is the weight or quantity of $1000 \mathrm{~g}$. This BM2 treatment is the best in producing liquid smoke. Although based on the yield calculation (\%), BM2 treatment shows a lower value than BM1; however, if it is calculated based on time efficiency and the results of the liquid smoke, BM2 treatment is still better. And what is not recommended is BM3 treatment because of the weight or quantity of raw materials, which is too much, causing it not to burn completely so that the smoke produced and condenses a little. This is not time efficient and the materials used are not utilized optimally.

\subsection{Quality of Liquid Smoke of Red Fruit Seed Waste}

The quality of liquid smoke is very dependent on the chemical components contained in it. Especially liquid smoke that can be used as a biopesticide must have a chemical content that supports its function as a biopesticide.

Table 4. Content of $\mathrm{pH}$, acid, and phenol content of liquid smoke of red fruit seed waste grade 3

\begin{tabular}{|l|l|l|l|}
\hline Treatment of & $\mathrm{pH}$ & Acid content (\%) & Phenol content (\%) \\
\hline $500 \mathrm{~g}$ & 3.20 & 13.96 & 4.94 \\
\hline $1000 \mathrm{~g}$ & 3.35 & 14.20 & 4.91 \\
\hline $1500 \mathrm{~g}$ & 3.27 & 13.73 & 5.11 \\
\hline
\end{tabular}

\subsection{1 pH Value}

The $\mathrm{pH}$ value is one of the quality parameters of the resulting liquid smoke. Measurement of the $\mathrm{pH}$ value in liquid smoke aims to determine the level of the decomposition process of raw materials by pyrolysis to produce organic acids in liquid smoke. The average $\mathrm{pH}$ value in the liquid smoke produced in the pyrolysis process of red fruit seed waste varies, as in table 3 . Based on table 3 , it can see that the $\mathrm{pH}$ value of liquid smoke from all treatment results is classified as acidic, ranging from 3.20 to 3.35 .

\subsubsection{Acid content (\%)}


Acid content is one of the essential parameters that determine the quality of the liquid smoke produced. The acid levels obtained in each treatment can be seen in Table 4. The acids derived from liquid smoke can affect the taste and pH (Wijaya et al., 2008) and significantly affect the total phenol produced. Luditama, (2006), stated that the antimicrobial properties of Liquid smoke would increase when organic acids are present together with phenol compounds. The acid content of the liquid smoke of red fruit seed waste is high when compared to the content of coconut shell liquid smoke in previous studies (Ishak, et al. 2019). It explained that the acid content of coconut shell liquid smoke showed a value of $13.93 \mathrm{mg} / \mathrm{mL}$ at a concentration of $7 \%$. The high and low acid content of liquid smoke is influenced by the cellulose content of the raw materials used.

\subsubsection{Phenol content (\%)}

Phenol content is a significant parameter to know in determining the quality of liquid smoke. The identification of phenolic compounds in liquid smoke is expected to represent the quality criteria requirements. The results of the analysis of total phenol are presented in Table 4 as follows. Table 4 data shows that the complete phenol content in liquid smoke ranges from 4.91 to $5.11 \%$. The phenol content contained in the liquid smoke of the red fruit seed waste is much higher when compared to the phenol content obtained in the study of Haji, et al., (2007), at a temperature of $350-510^{\circ} \mathrm{C}$ produces an average phenol content of $0.012 \%$ with the raw material of pyrolysis of solid organic waste. Another study conducted by Rasi \& Yulius (2016), obtained a moderate phenol content of $3.88 \%$ at a temperature of $300-500^{\circ} \mathrm{C}$ in liquid smoke resulting from the pyrolysis of coconut shells. In another study by Sitanggang and Sigalingging, (2018) with the raw material liquid smoke from rice husk, average levels of phenols ranged from 0.0051 to $0.0074 \%$. Judging from the high levels of phenol, this indicates that the liquid smoke from the waste of red fruit seeds can be used as a biopesticide. The presence of a high phenol content can make liquid smoke a biopesticide that is repellent and anti-eating by insects. The presence of phenol can provide an aroma that insects do not like.

\section{Conclusions and Suggestion}

conclusions that it can draw based on the results of the study are the yield and the quality of liquid smoke in the form of $\mathrm{pH}$ values, acid levels, and phenol levels of red fruit seed waste as raw material for grade 3 liquid smoke by using a pyrolysis tool that has the potential as a good biopesticide in controlling pests. The recommended weight or quantity of raw material for red fruit seed waste that produces more liquid smoke is BM2 treatment with a weight of $1000 \mathrm{~g}$ of raw material having a pH value of 3.35 , acid content of $14.20 \%$, and total phenol content of $4.91 \%$. The high acid content ranging from $13.73-14.20 \%$ and the high phenol content ranging from 4.91-5.11\% compared to the raw materials for liquid smoke of rice husk, coconut shell, and organic waste, makes the liquid smoke of red fruit seed waste a biopesticide that is repellent and anti-insect eating. Because the presence of acids and phenols can provide an aromatic that insects do not like.

Suggestions that it can carry out are the need for further research to test the biopesticide of liquid smoke from red fruit seed waste on the mortality of pests or plant-disturbing organisms in agricultural crop commodities because it has the potential for effective control and is one of the environmentally-friendly control techniques.

Acknowledgments: The authors would like to thank the Directorate of Research and Community Service (DRPM DIKTI) for the assistance of funds to support research activities with the contract number T/27LL14/KS/20/.

\section{References}

[1] Ariestya, D. I., Swastawati, F., \& Susanto, E. (2016). Antimicrobial activity of microencapsulation liquid smoke on tilapia [Oreochromis niloticus (Linnaeus, 1758)] meat for preservatives in cold storage ( \pm 5 C). Aquatic procedia, 7, 19-27.

[2] Anderson, E. J., Ali, M. L., Beavis, W. D., Chen, P., Clemente, T. E., Diers, B. W., ... \& Tilmon, K. J. (2019). Soybean [Glycine max (L.) Merr.] b

[3] Girard, J. P. (1992). Technology of meat and meat products. Ellis Horwood.

[4] Herwati E., Prarudianto, A and Saloko S. (2017). Effect of concentration of coconut shell liquid smoked powder (Cocos nucifera Linn) and storage time on the quality of milkfish preto smoked. Scientific journal of Agricultural Engineering and Biosystems. 5(1): 348-359.

[5] Ishak I., Musa, WJA, \& Rahman, SW. (2019). Utilization of Coconut Shell Liquid Smoke as an Organic Pesticide against the Mortality of Armyworms (Spodoptera litura F.). Jamb.J.Chem., 01(1), 15-20.

[6] Lingbeck, J. M., Cordero, P., O'Bryan, C. A., Johnson, M. G., Ricke, S. C., \& Crandall, P. G. (2014). Functionality of liquid smoke as an all-natural antimicrobial in food preservation. Meat Science, 97(2), 197-206.

[7] Sari YP, Samharinto, and Langai BF. (2018). The use of liquid smoke from oil palm empty bunchesTKKS fruit as a vegetable pesticide to control leaf destroying pests of mustard greens (Brassica juncea L.). Journal of EnviroScienteae. 4(3): 272-284.

[8] Sarwendah M., Feriadi, T. Wahyuni, and Arisanti TN. (2019). Utilization of plantation commodity waste for the manufacture of liquid smoke. Littri Journal. 25(1): 22 - 30.

[9] Suhanda. (2016). Utilization of Liquid Smoked Cashew Seed Shells as Pesticides. Essay. Chemical Engineering Department. Industrial Technology Faculty. Indonesian Muslim University.

[10] Vachlepi A., and Suwardin D. (2015). Characteristic of iron metal corrosion in liquid smoke coagulant. International symposium on applied chemistry. Journal of Procedia Chemistry. 16 (2015): 420 - 426. 
[11] Wagiman FX, Ardiansyah, A and Witjaksono. (2014). The activity of coconut shell liquid smoke as an insecticide on the rice brown planthopper (Nilaparvata lugens). Journal of Agricultural and Biological Science. 9(9): 293-296.

[12] Wijaya, M., Noor E., Irawadi T. T., and Pari G. (2008). Characterization of the Chemical Components of Liquid Smoke and Their Use as Biopesticides. Bionature.9(1): 34-40.

[13] Yatagai, M., (2002). Utilization of Charcoal and Wood Vinegar in Japan. Journal of Food Science. Graduate School of Agricultural and Life Sciences. The University of Tokyo.

[14] Yunus. (2011). Technology for making liquid smoke from coconut shells as a food preservative. Journal of Science and Innovation. 7(1): 5361.

[15] Yusnaini and Indah R. (2014). Production and Quality of Liquid Smoke From Various Types of Raw Materials. Proceedings of SNaPP2014 Science, Technology, and Health. 4(1): 253-260.

[16] Zultinar. (2014). The Effect of Temperature and Time Variations on Pyrolysis Yield of Durian Peel Waste into Liquid Smoke. Essay. Department of Chemical Engineering, Riau University, Pekan baru. 